\title{
Nova domesticidade: a opção feminina pelo lar
}

\author{
Homeward Bound: why women are \\ embracing the new domesticity. \\ MATCHAR, Emily. \\ Nova York: Simon \& Schuster, 2013.288 p.
}

Em seu primeiro livro, Homeward Bound: why women are embracing the new domesticity, Emily Matchar se propõe a explicar o fenômeno que ela chama de "nova domesticidade", referindo-se à retomada das atividades tradicionalmente consideradas domésticas e femininas como artesanato, jardinagem, cozinha natural e maternidade intensiva - pelas jovens mulheres urbanas e de alto nível de educação formal. A jovem autora saída de Harvard cita a proliferação de blogs e lojas virtuais de produtos artesanais como indícios claros dessa tendência de comportamento. Por meio de entrevistas, Matchar analisa o contexto contemporâneo dos Estados Unidos e aponta como principais causas a preocupação com a sustentabilidade e a saúde; a busca da sensação de estabilidade e segurança de um "passado cor-de-rosa"; a realização pessoal; e a necessidade de flexibilidade frente a um mercado de trabalho em recessão, que não oferece oportunidade aos jovens e discrimina as mães. Como consequências, aponta o risco financeiro das mulheres que desistem de seus empregos formais, seduzidas pela ilusão de perfeição vendida pelos poucos casos de sucesso das blogueiras e empreendedoras virtuais; a paralização das demandas feministas por mudanças numa cultura de trabalho estagnada no modelo provedor masculino de tempo integral; e a inversão de valores no momento que uma classe privilegiada se apropria das atividades antes realizadas por necessidade financeira e sujeita às relações de poder entre gêneros como forma de status.

Matchar inicia a obra apresentando ao leitor o conceito de domesticidade e o histórico do trabalho feminino na sociedade. Em seguida, para tratar minuciosamente dos diversos assuntos abrangidos pela nova domesticidade, a autora centraliza cada capítulo em torno de um tema principal: a (re)construção da imagem da domesticidade na internet; artesanato; culinária e a alimentação; e maternidade intensiva - sem deixar de estabelecer vínculos entre os assuntos. Finalmente, ela analisa a relação entre a nova geração de mulheres e o mercado de trabalho, estabelecendo conexões diversas com a agenda feminista, e conclui com uma reflexão sobre o valor simbólico do retorno ao lar na sociedade contemporânea e as implicações dessa escolha.

O primeiro assunto tratado é a teoria da autora sobre o apelo da domesticidade nos dias de hoje. Ela conta que a vida no lar já foi romantizada outras vezes, como, por exemplo, nos anos 1950, mas o que diferencia o momento atual é a adoção do pensamento por parte de americanas progressistas e com alto nível de educação formal, o que sinaliza uma profunda mudança social. A nova domesticidade é, portanto, o acoIhimento dos valores domésticos por parte de pessoas que teriam condições financeiras e intelectuais de rejeitá-los. Sobre isso, existem olhares otimistas de ambos os lados: pela direita, as mulheres finalmente perceberam a importância de resgatar as tradições; pela esquerda, atingiuse o momento do pós-feminismo, no qual as muIheres são livres para optar pela domesticidade sem culpa. Entretanto, Matchar sugere maior atenção ao impacto consequente desse movimento.

Ao abordar brevemente a história do trabaIho feminino, ressalta-se a influência da Revolução Industrial ao prover os lares com produtos prontos ou semiprontos. As mulheres deixaram de fazer e passaram a consumir, o que perdurou até a década de 1920, depois disso a recessão econômica e a Segunda Guerra forçaram as então donas de casa a participar do mercado de trabalho. Já na prosperidade do pós-guerra, a figura materna foi novamente exaltada, até que em 1970 as circunstâncias econômicas fizeram a mulher voltar ao trabalho e posteriormente, com o aval do feminismo, tentar alcançar os cargos até então ocupados apenas por homens. Essa rejeição à figura da dona de casa dominou as décadas de 1980 e 1990, mas no início dos anos 2000 já havia pontualmente ações de resgate à cultura do DIY (do-it-yourself ou façavocê-mesmo), que acabaram culminando em popularidade após a crise econômica de 2008.

Essa data coincide com a ascensão dos blogs de estilo de vida que, segundo a autora, são em grande parte responsáveis pela dissemi- 
nação da cultura da domesticidade. A internet permite o contato com outras pessoas que compartilham os mesmos gostos e valorizam o trabaIho alheio, mesmo na segurança do lar; isso faz com que a dona de casa não seja mais a figura solitária e menosprezada da década de 1950, e sim uma mulher fortalecida e reconhecida por sua opção de estar em casa. Também na internet surgiu o fenômeno Etsy, um site que permite aos artesãos criar sua própria loja virtual e comercializar seus produtos ao redor do mundo. A autora considera esse sucesso interessante, pois ele expõe como o fazer manual cresceu e deu origem a uma economia artesanal representada principalmente pela insatisfação das mulheres com o mercado de trabalho, e o atribui à necessidade da geração $Y$ de empreender e expressar sua criatividade e individualidade, sobretudo diante de perspectivas profissionais desanimadoras. Porém, Matchar reforça que, em ambos os casos, a imagem de sucesso é construída e revela apenas o lado romântico da dedicação ao lar. Por trás dessa opção, existe uma série de dificuldades e fracassos que acabam sendo omitidos para vender ao leitor a ilusão de perfeição.

Voltando aos blogs, Matchar trata, então, da culinária, que é abordada não apenas como um prazer resultante do fazer manual, mas também como uma solução para problemas sociais como a obesidade infantil, o aquecimento global e o enfrentamento às grandes corporações. A geração $Y$, criada por suas mães trabalhadoras à base de enlatados e congelados, agora deseja o oposto para suas famílias e, mais do que nunca os consumidores estão atentos aos rótulos, optando por produtos orgânicos ou oriundos de hortas domésticas e adotando o vegetarianismo ou o veganismo. Esse capítulo está diretamente ligado ao seguinte, que trata da maternidade intensiva, uma corrente que prega a adoção do parto natural, a amamentação prolongada, a educação em casa, a abolição das fraldas e até o extremo de negar a vacina aos bebês. Matchar relaciona o comportamento à falta de confiança nas políticas governamentais que deveriam garantir a fiscalização dos alimentos, do serviço de saúde e da educação de qualidade, mas explicita que apenas uma parcela da população possui essa opção e, ao abandonar as demandas direcionadas aos governos por melhorias sociais, são os menos favorecidos que sofrerão as consequências.

A autora reforça que a característica principal da nova domesticidade é a opção por tal estilo de vida. São mulheres com alło nível de educação formal que abandonam seus bons empregos para transformar radicalmente a maneira de viver, frustradas por não conseguirem equilibrar a vida profissional e a maternidade, como prometiam as feministas. Motivadas pelos fatores citados nos capítulos anteriores, essas mulheres empunham a bandeira da desaceleração, rejeitando a cultura de consumo extrema e romantizando o tempo de suas avós, que aos seus olhos parecem mais simples e sinceros. Matchar sugere consequências graves advindas desse comportamento, sendo a principal a paralização da demanda por maior flexibilidade e condições de trabalho às mulheres.

Finalmente, Matchar fala como a nova domesticidade é de interesse e, consequentemente, integra grupos de repertórios distintos. Nesse contexto, as atitudes ultraprogressistas se aproximam do ultraconservadorismo, pois, embora as motivações sejam bastante diferentes, o resultado é o mesmo: mães cristãs e casais homossexuais trocam informações sobre a educação em casa; famílias de baixa renda vivem uma vida frugal por necessidade, enquanto outras abastadas o fazem pela forte crença na sustentabilidade; jovens urbanos trocam receitas e aprendem tricô com idosos que sempre levaram uma vida rural.

A autora toma o cuidado de expor opiniões divergentes sobre 0 assunto, trazendo olhares internos e externos - tanto o otimismo de quem vivencia e acredita nos benefícios do retorno ao lar quanto o pessimismo de quem considera o movimento um retrocesso para as conquistas feministas. Porém Matchar, que em diversos momentos fala de sua própria experiência em relação aos anseios domésticos, mostra-se firme em seu posicionamento, apropriando-se de argumentos dos ambos os lados para refutar pensamentos contrários.

O trabalho de Matchar é uma leitura válida para profissionais e pesquisadores interessados na sociedade contemporânea, pois proporciona desde uma análise de novos padrões de consumo até uma reflexão sobre macrotendências de comportamento voltadas à desaceleração. É também um ponto de partida para quem se proponha a desdobrar a pesquisa numa abordagem local, investigando as causas e consequências do resgate da domesticidade no território brasileiro, além de instigar o aprofundamento sobrecada um dos tópicos tratados em seus capítulos.

Daniele M. Lugli

Faculdade de Tecnologia SENAI - Curitiba 